\title{
PENGEMBANGAN PERANGKAT PEMBELAJARAN KIMIA BERBASIS STRATEGI BELAJAR PETA KONSEP UNTUK MENINGKATKAN PEMAHAMAN KONSEP DAN KEMAMPUAN BERPIKIR KRITIS SISWA SMA
}

\author{
Aditya Pratama'), Leny Yuanita ${ }^{2)}$, Endang Susantini ${ }^{3)}$ \\ ${ }^{1)}$ Mahasiswa Program Studi Pendidikan Sains, Program Pascasarjana Universitas Negeri Surabaya \\ 2), 3)Dosen Pascasarjana Prodi Pendidikan Sains Univesrtitas Negeri Surabaya \\ E-mail:helium_neverdie@yahoo.com
}

\begin{abstract}
The purpose of this research is produce chemistry teaching material using concept map strategy that valid, practical, and effective to improve understanding of concept and critical thingking ability of student in senior high school. The development of teaching material used to four D Models and was tested to 2 classes in class X of SMAN 1 Muara Bengkal second semester in academic year 2014/2015. Teaching material tested to One-Group Pretest-Posttest Design. Tested of teaching material used to one group pretest and posttest design. The data collection used observation method, test, and quetionnaires. The data analysis techniques used descriptive analysis of quantitative, qualitative and statistic non parametric. The results of this research are: 1) Teaching material developed has a valid category; 2) The practicality of teaching material in terms of a good category in feasibility of lesson plans and the students activities in accordance with steps of direct instruction using concept map strategy; and 3) The teaching material effectiveness in terms of: (a) Improving understanding of concept and critical thingking ability of student by getting the n-gain score from students and the result of non parametric analysis (b) The students' responds toward material and implementation of teaching are very positive. It's conclusion that the teaching material through concept map strategy are valid, practical, and effective to improve understanding of concept and critical thingking ability of student in senior high school.
\end{abstract}

Key Words: Teaching Material, Concept Map Strategy, Understanding of Concept, Critical Thingking Ability

Abstrak: Penelitian ini bertujuan untuk menghasilkan perangkat pembelajaran Kimia yang berbasis strategi belajar peta konsep yang valid, praktis, dan efektif untuk meningkatkan pemahaman konsep dan kemampuan berpikir kritis siswa SMA. Pengembangan perangkat pembelajaran menggunakan model 4-D dan diujicobakan pada 2 kelas di kelas X SMA Negeri 1 Muara Bengkal pada semester genap tahun ajaran 2014/2015. Ujicoba perangkat pembelajaran menggunakan rancangan One-Group Pretest-Posttest Design. Pengumpulan data menggunakan metode observasi, tes, dan angket. Teknik analisis data menggunakan analisis deskriptif kuantitatif, kualitatif dan uji statistik nonparametrik. Temuan hasil penelitian, yaitu: 1) Perangkat pembelajaran yang dikembangkan berkategori valid; 2) Kepraktisan perangkat pembelajaran ditinjau dari keterlaksanaan RPP berkategori baik dan aktivitas siswa sesuai dengan tahapan-tahapan pada model pembelajaran langsung yang menerapkan strategi belajar peta konsep; dan 3) Keefektifan perangkat pembelajaran ditinjau dari: (a) Peningkatan Hasil belajar pemahaman konsep dan kemampuan berpikir kritis siswa yang terlihat dari nilai n-gain masing-masing siswa serta hasil analisis data nonparametrik yang telah dilakukan; (b) Respon siswa terhadap perangkat dan pelaksanaan pembelajaran sangat positif. Disimpulkan bahwa perangkat pembelajaran kimia berbasis strategi belajar peta konsep yang dikembangkan valid, praktis, dan efektif untuk meningkatkan pemahaman konsep dan kemampuan berpikir kritis siswa SMA.

Kata kunci: Perangkat Pembelajaran, Strategi Belajar Peta Konsep, Pemahaman Konsep, Kemampuan Berpikir Kritis.

\section{PENDAHULUAN}

Kimia berasal dari bahasa Mesir "Keme" yang berarti "bumi" adalah ilmu yang mempelajari tentang komposisi, stuktur, dan sifat materi, beserta segala perubahan yang menyertai terjadinya reaksi kimia. Kimia merupakan cabang dari IPA memiliki peranan sangat penting terhadap perkembangan ilmu-ilmu terapan seperti: pertanian, kesehatan, perikanan dan ilmu terapan yang lainnya (Cahyana, 2004). Peranan ilmu kimia yang sangat penting ini akan menunjang keberhasilan dari ilmu-ilmu lain yang menggunakan ilmu kimia dalam penerapan ilmunya, akan tetapi berdasarkan kenyataan di lapangan ilmu kimia merupakan mata pelajaran yang cukup sulit bagi sebagian siswa SMA/MA. Kean dan Middlecamp (1985) menyatakan bahwa kesulitan ilmu kimia ini terkait dengan ciri-ciri atau karakteristik ilmu kimia itu sendiri, diantaranya sebagian ilmu kimia bersifat abstrak dan pokok bahasan yang dipelajari dalam ilmu kimia sangat banyak dengan karakteristik yang 
berbeda-beda pada setiap pokok bahasan. Ilmu kimia yang bersifat abstrak tersebut menyebabkan materi kimia sulit dipahami dan siswa tidak tertarik mempelajari ilmu kimia.

Kesulitan dalam mempelajari ilmu kimia yang dialami oleh siswa juga diketahui berdasarkan hasil observasi berupa angket yang diisi oleh siswa dan hasil dokumentasi nilai ujian semester siswa kelas X SMA Negeri 1 Muara Bengkal. Pada observasi tersebut dapat diketahui bahwa sebagian besar siswa mengalami kesulitan dalam mempelajari ilmu Kimia di sekolah khususnya pada pokok bahasan Ikatan Kimia dan siswa tidak tertarik dalam mempelajari ilmu kimia dengan persentase sebesar $93,33 \%$.

Observasi terhadap proses pembelajaran juga dilakukan, khususnya terhadap Rencana Pelaksanaan Pembelajaran (RPP) yang dilakukan oleh guru di SMA Negeri 1 Muara Bengkal pada tahun ajaran 2013/2014. Hasil telaah menunjukkan bahwa (1) guru melaksanakan proses pembelajaran yang berpusat pada guru; (2) guru paling sering menggunakan metode ceramah dalam pembelajaran; (3) guru jarang melaksanakan pembelajaran dengan menggunakan metode eksperimen di laboratorium; dan (4) pada saat memberikan tes, guru hanya memberikan soal tes bersifat berpikir tingkat rendah (hafalan) dan belum sampai pada soal tes yang bersifat berpikir tingkat tinggi, sehingga kemampuan berpikir kritis yang dimiliki oleh anak tidak tereksplor dengan baik. Hal ini tercermin dalam hasil tes ujicoba untuk mengetahui sejauh mana pemahaman konsep dan kemampuan berpikir kritis siswa setelah proses pembelajaran.

Berdasarkan analisis hasil tes uji coba yang telah dilakukan pada siswa kelas X IPA SMA Negeri 1 Muara Bengkal tahun ajaran 2013/2014 yang berjumlah 30 orang pada pokok bahasan Ikatan Kimia untuk mengetahui pemahaman konsep dan kemampuan berpikir kritis yang dimiliki oleh siswa, didapatkan data hanya $33,33 \%$ jawaban benar atas pertanyaan yang berkaitan dengan soal tes pemahaman konsep, sedangkan soal yang berkaitan dengan berpikir kritis (menganalisis) hanya $13,33 \%$ siswa yang menjawab benar. Kemampuan berpikir pada tahap menganalisis merupakan kemampuan berpikir tingkat tinggi, sedangkan untuk hafalan merupakan kemampuan berpikir tingkat rendah. Oleh sebab itu dapat disimpulkan bahwa pemahaman konsep dan kemampuan berpikir tingkat tinggi (berpikir kritis) siswa masih rendah.

Banyak cara yang dapat digunakan untuk membangun pengetahuan siswa yang nantinya diharapkan dapat meningkatkan pemahaman konsep dan kemampuan berpikir kritis terhadap materi yang disampaikan oleh guru, salah satunya dengan menggunakan strategi belajar. Penggunaan strategi belajar yang tepat dan cocok pada suatu pokok bahasan yang akan diajarkan dapat mempermudah siswa memahami konsep-konsep kimia yang disampaikan oleh guru dan mengasah kemampuan berpikir kritis yang dimiliki siswa tersebut dalam proses pembelajaran sehingga diharapkan proses pembelajaran dapat berlangsung secara efektif, efisien dan berkesinambungan.

Salah satu alasan mengapa strategi-strategi belajar perlu diajarkan pada siswa adalah untuk mengajarkan kepada para siswa bagaimana belajar, mengingat, berpikir, dan memotivasi diri mereka sendiri. Pengajaran strategi berlandaskan pada dalil bahwa keberhasilan siswa sebagian besar bergantung pada kemahiran untuk belajar secara mandiri dan memonitor belajar mereka sendiri. Hal tersebut seperti yang diungkapkan oleh Nur (2011: 5) : "Strategi-strategi belajar mutlak diajarkan kepada siswa secara tersendiri, mulai dari kelas-kelas rendah sekolah dasar dan terus berlanjut sampai sekolah menengah dan pendidikan tinggi".

Berdasarkan pemikiran konstruktivisme, materimateri yang diajarkan kepada siswa akan sulit dipahami jika guru menyampaikannya hanya dengan metode ceramah. Terlebih lagi dengan materi yang terdapat dalam pokok bahasan Ikatan Kimia, pada pokok bahasan tersebut siswa dituntut untuk mengembangkan pengetahuannya karena memiliki terdapat banyak konsep dasar dan informasi baru yang sangat penting serta saling memiliki keterkaitan antara konsep yang satu dengan konsep yang lainnya ataupun dengan pokok bahasan lain yang akan diajarkan maupun yang telah diajarkan kepada siswa. Hal ini menuntut dan menantang seorang guru untuk dapat menghasilkan perangkat pembelajaran dan menyajikan pembelajaran yang sesuai dengan karakteristik pokok bahasan Ikatan Kimia tersebut. Keadaan tersebut mendorong peneliti untuk menerapkan strategi belajar dan model pembelajaran yang tepat yang disesuaikan dengan karakteristik pokok bahasan Ikatan Kimia tersebut. Pemilihan strategi belajar yang tepat dan sesuai di dalam pembelajaran tersebut diharapkan agar pemahaman konsep siswa bisa meningkat dan siswa dapat kemampuan berpikir kritisnya di dalam proses pembelajaran.

Menurut Kilic \& Cakmak (2013) berdasarkan hasil penelitian yang telah dilakukan, salah satu strategi pembelajaran untuk menghasilkan pemahaman konsep yang maksimal adalah strategi belajar peta konsep. Hal tersebut diperkuat dengan pernyataan Dahar (2011) yang menyatakan bahwa "Dengan menggunakan strategi belajar peta konsep ini membuat siswa akan lebih mudah dalam menyerap materi yang diajarkan dalam proses pembelajaran dan siswa dapat mengaitkan informasi baru dengan konsep-konsep relevan yang ada 
pada struktur kognitif siswa sehingga dapat meningkatkan pemahaman konsep dan memaksimalkan kemampuan berpikir kritis siswa selama proses pembelajaran".

Novak dan Gowin (1984) menyatakan bahwa peta konsep (concept map) adalah suatu istilah tentang strategi yang digunakan guru untuk membantu siswa mengorganisasikan konsep pelajaran yang telah dipelajari berdasarkan arti dan hubungan antara komponennya. Hubungan antara satu konsep dengan konsep lain dikenal sebagai proposisi. Peta konsep merupakan suatu alat yang efektif menghadirkan secara visual hirarki generalisasi-generalisasi dan untuk mengekspresikan keterkaitan proposisi dalam sistem konsep-konsep yang saling berhubungan. Jonnasen dalam Rosen (2013) menyatakan bahwa pembuatan peta konsep dapat membuat siswa untuk berpikir tentang ranah isi (content domain) supaya mengenal dan menguji konsep-konsep penting, mengklasifikasi konsep-konsep tersebut, menggambarkan hubungan antara konsep-konsep, menganalisis sifat hubungannya dan membuat kaitan atau hubungan dengan menggunakan kemampuan berpikir tingkat tinggi (berpikir kritis) yang mereka miliki.

Penelitian mengenai strategi belajar peta konsep untuk meningkatkan pemahaman konsep siswa dapat dideskripsikan dari hasil penelitian yang telah dilakukan oleh beberapa peneliti sebelumnya diantaranya yaitu Markow \& Lonning (1998) yang melaporkan bahwa dengan menggunakan strategi belajar peta konsep pemahaman konsep mahasiswa mengalami perkembangan yang positif. Vanides (2005) melaporkan bahwa penggunaan strategi belajar peta konsep pada penelitian di kelas sains telah memberikan masukan bahwa strategi belajar peta konsep lebih akurat merefleksikan perbedaan struktur pengetahuan siswa, mendeteksi pemahaman dan miskonsepsi, memberikan ruang lebih bebas kepada siswa untuk menentukan pemahaman konsep mereka dan siswa memperoleh high-order cognitive process, sedangkan Wilgis \& Mc Connel (2002) melaporkan bahwa dengan menggunakan strategi belajar peta konsep dapat meningkatkan kemampuan berpikir kritis mahasiswa keperawatan.

Penelitian lain tentang strategi peta konsep ini telah dilakukan sebelumnya oleh (Elvinawati,2011; Chiou, 2008; Otor dan Emmanuel, 2013) yang melaporkan bahwa hasil belajar dan ketuntasan belajar mahasiswa dengan menggunakan strategi belajar peta konsep dapat meningkat. Pada penelitian tersebut, Elvinawati (2011) menambahkan bahwa dengan menggunakan strategi belajar peta konsep aktivitas dan pemahaman konsep mahasiswa mengalami peningkatan pada proses pembelajaran. Pada penelitian yang telah dilakukan oleh (Juliarti, 2011; Azis dan Jair, 2009) menunjukkan bahwa dengan menggunakan strategi belajar peta konsep juga dapat meningkatkan minat dan motivasi belajar siswa.

Berdasarkan uraian dan penjelasan di atas maka dipilih strategi belajar peta konsep (concept map) untuk meningkatkan pemahaman konsep dan kemampuan berpikir kritis pada materi Ikatan Kimia. Alasan pemilihan strategi belajar peta konsep ini karena sesuai dengan karakteristik pokok bahasan Ikatan Kimia yang memiliki banyak konsep dasar dan informasi baru yang sangat penting serta saling memiliki keterkaitan antara konsep yang satu dengan konsep yang lainnya ataupun dengan pokok bahasan lain yang akan diajarkan maupun yang telah diajarkan kepada siswa dan belum tersedianya perangkat pembelajaran materi Ikatan Kimia yang berbasis strategi belajar peta konsep maka perlu dilakukan penelitian pengembangan perangkat pembelajaran tersebut yang mengacu pada kurikulum 2013. Perangkat pembelajaran yang berbasis strategi belajar peta konsep tersebut nantinya diharapkan dapat meningkatkan pemahaman konsep dan kemampuan berpikir kritis siswa pada pokok bahasan Ikatan Kimia di SMA Negeri 1 Muara Bengkal.

\section{METODE PENELITIAN}

Penelitian ini merupakan penelitian pengembangan karena mengembangkan perangkat pembelajaran kimia dengan strategi belajar Peta Konsep untuk meningkatkan pemahaman konsep dan kemampuan berpikir kritis siswa SMA. Perangkat pembelajaran yang dikembangkan adalah Rencana Pelaksanaan Pembelajaran (RPP), Buku Siswa, Lembar Kerja Siswa (LKS) dan Tes Hasil Belajar (THB) Siswa. Perangkat yang telah dikembangkan akan melalui uji 1 pada sampel kecil dan uji 2 pada sampel besar dengan replikasi dua kelas. Desain uji coba perangkat menggunakan rancangan eksperimen Pre and Post Design, yang dapat digambarkan sebagai berikut:

\section{$\begin{array}{lll}\mathbf{O}_{1} & \mathbf{X} & \mathbf{O}_{2}\end{array}$}

Keterangan:

$\mathrm{O}_{1}=$ Pengujian awal (pre-test) sebelum perlakuan

$\mathrm{O}_{2}=$ Pengujian akhir (post-test) setelah perlakuan

$\mathrm{X}=$ Perlakuan (treatment) berupa pembelajaran dengan menggunakan strategi belajar peta konsep

Teknik pengumpulan data yang digunakan dalam penelitian ini adalah observasi, pemberian tes dan penyebaran angket. Data tes hasil belajar yang meliputi hasil belajar aspek sikap, pengetahuan, dan keterampilan dianalisis secara deskriptif kualitatif dan statistik nonparametrik. 


\section{HASIL DAN PEMBAHASAN}

\section{A. Hasil Validasi Perangkat Pembelajaran}

Perangkat pembelajaran yang dikembangkan pada penelitian ini adalah Buku Ajar Siswa, Rencana Pelaksanaan Pembelajaran (RPP), Lembar Kerja Siswa (LKS), dan Tes Hasil Belajar (THB). Hasil pengembangan perangkat pembelajaran kimia berbasis strategi belajar peta konsep untuk meningkatkan pemahaman konsep dan kemampuan berpikir kritis yang dikembangkan telah valid untuk digunakan dalam pembelajaran setelah mendapatkan saran dan penilaian dari para ahli. Berikut ini hasil validasi dari beberapa perangkat pembelajaran yang telah dikembangkan.

Buku ajar siswa yang dikembangkan berupa buku cetak yang diadopsi dari buku-buku kimia yang relevan dengan materi yang akan diajarkan dan mengikuti tata cara penulisan buku ajar kurikulum 2013. Hasil analisis data dari validasi buku siswa secara ringkas dapat dilihat pada Tabel 1 berikut ini.

Tabel 1. Hasil Validasi Buku Ajar Siswa

\begin{tabular}{|c|c|c|c|c|c|c|}
\hline \multirow{2}{*}{ Aspek yang dinilai } & \multicolumn{3}{|c|}{ Penilaian } & \multirow{2}{*}{ Rata-rata } & \multirow{2}{*}{$\mathbf{K}$} & \multirow{2}{*}{$\mathrm{R}(\%)$} \\
\hline & V1 & $\mathrm{V} 2$ & $\mathrm{V3}$ & & & \\
\hline \multicolumn{7}{|c|}{ Organisasi sub konsep } \\
\hline A. Pendahuluan & 3 & 3 & 3 & 3 & $\mathrm{~V}$ & 100 \\
\hline B. Isi & 3,82 & 3,73 & 3 & 3,52 & SV & 88 \\
\hline C. Penutup & 4 & 3 & 3 & 3,33 & $\mathrm{~V}$ & 85,71 \\
\hline Penjabaran konsep & 3,86 & 3,71 & 3,43 & 3,67 & SV & 94,10 \\
\hline \multicolumn{4}{|c|}{ Rata-rata } & 3,38 & V & 91,95 \\
\hline
\end{tabular}

Keterangan:

V1: Validator 1; V2: Validator 2; V3: Validator 3; K: Kategori; $\quad \mathrm{R}(\%)$ : Reliabilitas(\%)

SV: Sangat Valid; V: Valid

Rencana Pelaksanaan Pembelajaran (RPP) yang dikembangkan didesain dalam empat kali pertemuan yang mengacu pada kurikulum 2013 dan Model Pembelajaran Langsung (MPL) yang menerapkan strategi belajar peta konsep. Hasil analisis data dari validasi RPP ringkas dapat dilihat pada Tabel 2 berikut ini.

Tabel 2. Hasil Validasi RPP

\begin{tabular}{|c|c|c|c|c|c|c|}
\hline \multirow{2}{*}{ Aspek yang Dinilai } & \multicolumn{3}{|c|}{ Penilaian } & \multirow{2}{*}{ Rata-rata } & \multirow{2}{*}{ K } & \multirow[t]{2}{*}{$\mathrm{R}(\%)$} \\
\hline & V1 & $\mathrm{V} 2$ & $\mathrm{V3}$ & & & \\
\hline Identitas & 4 & 4 & 4 & 4 & SV & 100 \\
\hline Tujlaxll & 3,75 & 4 & 3,25 & 3.67 & SV & 89,67 \\
\hline Metode Pembelajaran & 3 & 4 & 4 & 3.67 & SV & 85,71 \\
\hline Sarana dan sumber belajar & 3,50 & 4 & 3,50 & 3,67 & SV & 93,33 \\
\hline Langkah Pembelajaran & 4 & 3,5 & 4 & 3.83 & SV & 93,33 \\
\hline Evaliasi & 3,67 & 4 & 3 & 3.56 & SV & 85,71 \\
\hline Keterbacaall & 4 & 4 & 4 & 4 & SV & 100 \\
\hline \multicolumn{4}{|c|}{ Rata-rata } & 3,77 & $\mathrm{SV}$ & 92,54 \\
\hline
\end{tabular}

Keterangan:

V1: Validator 1; V2: Validator 2;

V3: Validator 3; K: Kategori;

$\mathrm{R}(\%)$ : Reliabilitas(\%)

SV: Sangat Valid; V: Valid

LKS yang dikembangkan peneliti mengajarkan siswa dalam mengenal konsep-konsep penting dan melatihkan kemampuan berpikir kritis di dalam proses pembelajaran sehingga diharapkan dapat meningkatkan pemahaman konsep dan kemampuan berpikir kritis siswa. Hasil analisis data dari validasi lembar kerja siswa secara ringkas dapat dilihat pada Tabel 3 berikut ini.

Tabel 3. Hasil Validasi Lembar Kerja Siswa

\begin{tabular}{|c|c|c|c|c|c|c|}
\hline \multirow{2}{*}{ Aspek yang dinilai } & \multicolumn{3}{|c|}{ Penilaian } & \multirow{2}{*}{ Rata-rata } & \multirow{2}{*}{ K } & \multirow{2}{*}{$\mathrm{R}(\%)$} \\
\hline & V1 & V2 & $\mathrm{V3}$ & & & \\
\hline Organisasi LKS & 3,5 & 4 & 4 & 3,83 & SV & 93,33 \\
\hline $\begin{array}{l}\text { Penjabaran rangkaiall } \\
\text { materi }\end{array}$ & 4 & 3,67 & 3 & 3,56 & SV & 85,71 \\
\hline Langkah Pembelajaran & 4 & 3,5 & 3 & 3,5 & SV & 85,71 \\
\hline Alat dan Bahan & 4 & 4 & 4 & 4 & SV & 100 \\
\hline \multicolumn{4}{|c|}{ Rata-l'ata } & 3,72 & SV & 91,19 \\
\hline
\end{tabular}

Soal tes hasil belajar yang dikembangkan dalam penelitian ini terdiri dari tes hasil belajar pemahaman konsep sebanyak 20 soal yang berbentuk pilihan ganda dan tes hasil belajar kemampuan berpikir kritis sebanyak 10 soal yang berbentuk uraian atau essai. Hasil analisis data dari validasi Tes Hasil Belajar kemampuan berpikir kritis dan pemahaman konsep siswa secara ringkas dapat dilihat pada Tabel 4 dan Tabel 4 berikut ini.

Tabel 4 .Hasil Validasi Tes Hasil Belajar Kemampuan Berpikir Kritis

\begin{tabular}{|c|c|c|c|c|c|c|c|c|c|c|c|c|}
\hline \multirow{3}{*}{$\begin{array}{l}\text { Butir } \\
\text { Soal } \\
\text { Tes }\end{array}$} & \multicolumn{12}{|c|}{ Aspek yang dinilai } \\
\hline & \multicolumn{6}{|c|}{ Validasi Isi } & \multicolumn{6}{|c|}{ Bahasa dan Penulisan Soal } \\
\hline & $\mathrm{vl}$ & V2 & v3 & $\begin{array}{l}\text { Rerata } \\
\text { Skor }\end{array}$ & $\mathbf{K}$ & $\mathrm{R}(\%)$ & $\mathrm{Vl}$ & V2 & V3 & $\begin{array}{l}\text { Rerata } \\
\text { Skor }\end{array}$ & $\mathbf{K}$ & $R(\%)$ \\
\hline 1 & 4 & 3 & 4 & 3,67 & SV & 85,71 & 3 & 3 & 4 & 3,33 & V & 85,71 \\
\hline 2 & 4 & 3 & 3 & 3,33 & V & 85,71 & 4 & 3 & 3 & 3,33 & V & 85,71 \\
\hline 3 & 4 & 4 & 3 & 3,67 & SV & 85,71 & 4 & 4 & 4 & 4 & SV & 100 \\
\hline 4 & 4 & 4 & 3 & 3,67 & SV & 85,71 & 4 & 3 & 3 & 3,33 & V & 85,71 \\
\hline 5 & 4 & 3 & 4 & 3,67 & SV & 85,71 & 3 & 4 & 4 & 3,67 & SV & 85,71 \\
\hline 6 & 3 & 3 & 3 & 3 & V & 100 & 4 & 4 & 4 & 4 & SV & 100 \\
\hline 7 & 3 & 4 & 3 & 3,33 & V & 85,71 & 4 & 3 & 4 & 3,67 & SV & 85,71 \\
\hline 8 & 4 & 3 & 4 & 3,67 & SV & 85,71 & 4 & 3 & 3 & 3,33 & V & 85,71 \\
\hline 9 & 4 & 4 & 4 & 4 & SV & 100 & 4 & 3 & 3 & 3,33 & V & 85,71 \\
\hline 10 & 4 & 3 & 3 & 3,33 & V & 85,71 & 4 & 4 & 3 & 3,67 & SV & 85,71 \\
\hline Rerata & 3,80 & 3,40 & 3,40 & 3,53 & SV & 88,57 & 3,80 & 3,40 & 3,50 & 3,57 & SV & 88,57 \\
\hline
\end{tabular}


Tabel 5.Hasil Validasi Tes Hasil Belajar Pemahaman Konsep

\begin{tabular}{|c|c|c|c|c|c|c|c|c|c|c|c|c|}
\hline \multirow{3}{*}{$\begin{array}{l}\text { Butir } \\
\text { Soal } \\
\text { Tes }\end{array}$} & \multicolumn{12}{|c|}{ Aspeti rang̣g diulail } \\
\hline & \multicolumn{6}{|c|}{ Validasi Isi } & \multicolumn{6}{|c|}{ Baluss dan Pendifsan Soal } \\
\hline & $\mathrm{Tl}$ & V: & 13 & $\begin{array}{l}\text { Rerata } \\
\text { Stloor }\end{array}$ & $\mathrm{K}$ & $R(\%)$ & $\mathrm{Vl}$ & V: & 13 & \begin{tabular}{|l} 
Renta \\
Stlor \\
\end{tabular} & $\mathrm{K}$ & $R(\%)$ \\
\hline 1 & 4 & 4 & 4 & 4 & SV & 100 & 3 & 3 & 4 & 3,33 & V & 85,71 \\
\hline 2 & 4 & 4 & 4 & 4 & SV & 100 & 4 & 4 & & 4 & SV & 100 \\
\hline 3 & 4 & 4 & 4 & 4 & SV & 100 & 4 & 4 & & 4 & SV & 100 \\
\hline 4 & 4 & 4 & 4 & 4 & SV & 100 & 4 & 4 & 4 & 4 & SV & 100 \\
\hline j & 4 & 4 & 4 & 4 & SV & 100 & 4 & 4 & 3 & 3,67 & SV & 85,71 \\
\hline 6 & 4 & 4 & 4 & 4 & SV & 100 & 3 & 4 & 4 & 3,33 & V & 85,71 \\
\hline 1 & 4 & 4 & 4 & 4 & SV & 100 & 3 & 4 & & 3,67 & SV & 85,71 \\
\hline 8 & 4 & 4 & 4 & 4 & SV & 100 & 4 & 3 & 4 & 3,67 & SV & 85,71 \\
\hline 9 & 4 & 4 & 4 & 4 & SV & 100 & 3 & 4 & 3 & 3,33 & V & 85,71 \\
\hline 10 & 4 & 4 & 4 & 4 & SV & 100 & 4 & 4 & 4 & 4 & SV & 100 \\
\hline 11 & 4 & 4 & 4 & 4 & SV & 100 & 4 & 4 & 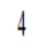 & 4 & SV & 100 \\
\hline 12 & 4 & 4 & 3 & 3,67 & SV & 85,71 & 3 & 4 & 4 & 3,67 & SV & 85,71 \\
\hline 13 & 4 & 4 & 4 & 4 & SV & 100 & 3 & 4 & 3 & 3,33 & V & 85,71 \\
\hline 14 & 4 & 4 & 4 & 4 & SV & 100 & 4 & 4 & 3 & 3,67 & SV & 85,71 \\
\hline 15 & 4 & 3 & 4 & 3,67 & SV & 85,71 & 4 & 3 & 3 & 3,33 & V & 85,71 \\
\hline 16 & 4 & 3 & 3 & 3,33 & V & 85,71 & 4 & 4 & 3 & 3,67 & SV & 85,71 \\
\hline 17 & 4 & 4 & 3 & 3,67 & SV & 85,71 & 3 & 4 & 3 & 3,33 & V & 85,71 \\
\hline 18 & 4 & 4 & 4 & 4 & SV & 100 & 4 & 4 & 4 & 4 & SV & 100 \\
\hline 19 & 4 & 3 & 3 & 3,33 & V & 85,71 & 4 & 3 & 3 & 3,33 & V & 85,71 \\
\hline 20 & 4 & 3 & 3 & 3,33 & V & 85,71 & 4 & 3 & 3 & 3,33 & $V$ & 85,71 \\
\hline Rerata & $t$ & 3,8 & 3,75 & 3,85 & $\mathrm{ST}$ & 95,71 & 3,65 & 3,75 & 3,50 & 3,63 & $\mathrm{ST}$ & 90 \\
\hline
\end{tabular}

\section{Keterangan:}

V1: Validator 1; V2: Validator 2; V3: Validator
3; K: Kategori; SV: Sangat Valid; V: Valid

\section{B. Hasil Ujicoba Perangkat Pembelajaran}

Hasil pengembangan perangkat pembelajaran kimia berbasis strategi belajar peta konsep untuk meningkatkan pemahaman konsep dan kemampuan berpikir kritis yang dikembangkan telah praktis untuk digunakan dalam proses pembelajaran berdasarkan hasil pengamatan keterlaksanaan perangkat pembelajaran pada kelas XA dan XB. Hasil pengamatan keterlaksanaan RPP yang dilakukan oleh dua orang guru sebagai pengamat disajikan pada Tabel 6 berikut ini.
Tabel 6.Hasil Penilaian Kualitas Keterlaksanaan RPP

\begin{tabular}{|c|c|c|c|c|c|c|c|c|c|}
\hline \multirow{3}{*}{ Tahap } & \multirow{3}{*}{ Aspek yang dinilai } & \multicolumn{4}{|c|}{$X A$} & \multicolumn{4}{|c|}{$X B$} \\
\hline & & \multicolumn{4}{|c|}{ Skor Penilaian } & \multicolumn{4}{|c|}{ Skor Penilaian } \\
\hline & & R1 & R2 & R3 & Rt & $\mathrm{R} 1$ & $\mathrm{R} 2$ & $\mathrm{R3}$ & $\mathrm{R} 4$ \\
\hline I & Pendahuluara & 3,33 & 3,50 & 3,67 & 3,83 & 3,42 & 3,58 & 3,67 & 3,83 \\
\hline II & Kegiatan Inti & 3,10 & 3,40 & 3,40 & 3,80 & 3,30 & 3,40 & 3,50 & 3,70 \\
\hline III & Pentrip & 3,50 & 3,50 & 3,50 & 3,83 & 3,75 & 3,88 & 3,88 & 4,00 \\
\hline IV & Suasana Kelas & 3,20 & 3,30 & 3,70 & 3,90 & 3,10 & 3,40 & 3,60 & 3,90 \\
\hline \multirow[t]{2}{*}{ V } & Pengelolaan Waktu & 3,00 & 3,50 & 3,50 & 4,00 & 3,00 & 3,50 & 3,50 & 4.00 \\
\hline & Persentanse ketertlalassmanam & \multicolumn{4}{|c|}{100} & \\
\hline
\end{tabular}

Keterangan:

R1: Pertemuan 1; R2: Pertemuan 2;

R3: Pertemuan 3; R4: Pertemuan 4

Dari hasil analisis data mengenai keterlaksanaan proses pembelajaran pada kelas X A dan X B ditemukan bahwa penilaian dari kegiatan pendahuluan, kegiatan inti dan kegiatan penutup yang diberikan oleh pengamat mengalami peningkatan pada setiap pertemuan. Hal tersebut mengindikasikan bahwa dalam proses pengajaran kualitas guru dalam menerapkan langkah-langkah pengajaran yang telah direncanakan sebelumnya berjalan dengan baik dan mengalami peningkatan kualitas dalam mengajar dan menerapkan RPP yang telah disusun.

Aktivitas siswa kelas XA dan XB selama proses pembelajaran yang diamati oleh dua orang pengamat disajikan pada Gambar 1 dan Gambar 2 berikut ini.

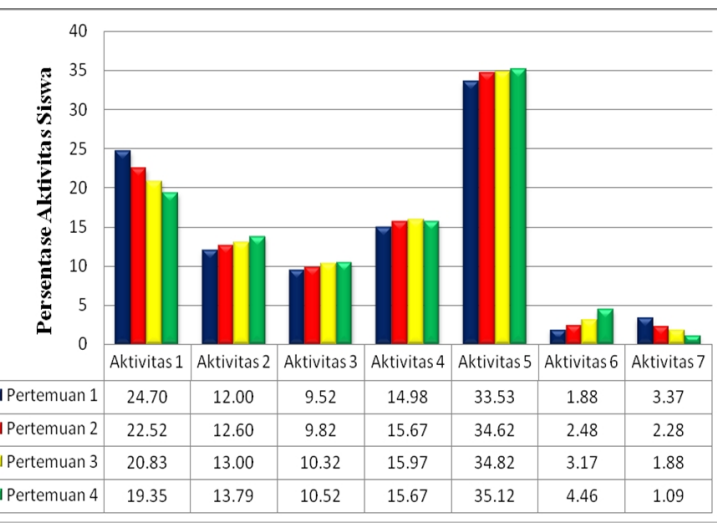

Gambar 1. Persentase Aktivitas Siswa Kelas XA

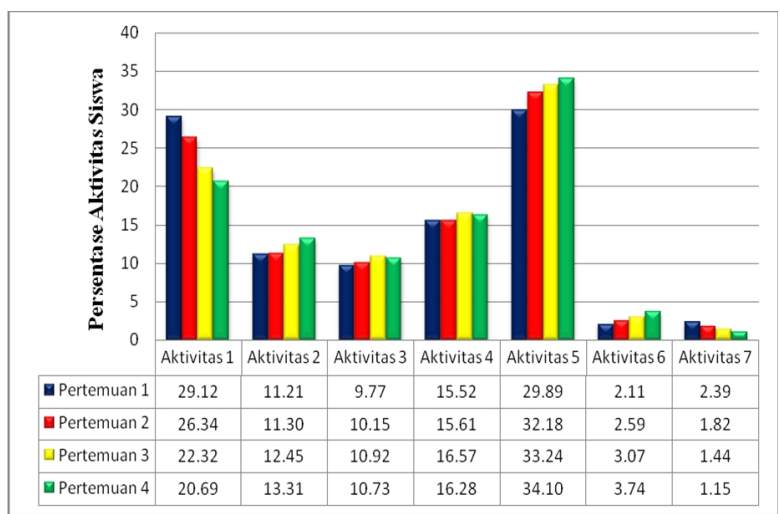

Gambar 2. Persentase Aktivitas Siswa Kelas XB

Keterangan: 
Aktivitas 1: Memperhatikan penjelasan guru

Aktivitas 2: Bertanya dan menanggapi pertanyaan (Diskusi)

Aktivitas 3: Menemukan konsep utama

Aktivitas 4: Menemukan konsep-konsep yang relevan dengan konsep utama

Aktivitas 5: Mengerjakan tugas di LKS (membuat peta konsep dan latihan soal)

Aktivitas 6: Mempresentasikan hasil kerja

Aktivitas 7: Berprilaku tidak relevan

Pembelajaran kimia yang menerapkan strategi belajar peta konsep menempatkan guru sebagai fasilitator dan siswa sebagai subyek pembelajaran, hal tersebut tergambar dari aktivitas siswa yang dominan dalam mengikuti proses pembelajaran, antara lain: menemukan konsep-konsep pada bahan bacaan dan mengerjakan LKS (membuat peta konsep) pada setiap pertemuan.

Aktivitas yang dominan pada siswa kelas X A dan $\mathrm{X}$ B dari pertemuan pertama sampai pertemuan keempat adalah aktivitas 5 (mengerjakan LKS). Aktivitas tersebut merupakan aktivitas dimana siswa membuat Peta Konsep dengan menganalisis konsepkonsep yang relevan pada bacaan yang disediakan oleh guru dan menyusun konsep-konsep tersebut dalam suatu hierarki yang tepat sehingga menghasilkan Peta Konsep serta melaksanakan praktikum (khusus pada pertemuan IV).

Pada saat rangkaian pelaksanaan proses pembelajaran pada kelas X A dan X B telah selesai, guru memberikan angket kepada siswa untuk mengetahui respon siswa terhadap proses pembelajaran yang telah dilaksanakan dan komponen pembelajaran yang diterapkan oleh guru. Sebagian besar siswa memberikan respon positif terhadap ketertarikan, keterbaharuan, kemudahan dalam memahami materi pelajaran yang disampaikan oleh guru dan berminat dalam mengikuti proses pembelajaran dengan menerapkan strategi belajar Peta Konsep pada Kegiatan Belajar Mengajar selanjutnya.

Respon tersebut menunjukkan bahwa siswa dapat menerima dengan baik semua komponen pembelajaran yang meliputi BAS, LKS, materi pembelajaran, suasana belajar dan cara guru mengajar. Berdasarkan hasil analisis dapat diketahui bahwa respon siswa terhadap pengembangan perangkat dan pelaksanaan pembelajaran selama uji coba 2 adalah positif dengan kategori sangat kuat. Hal ini berarti siswa mendukung, merasa senang, dan berminat terhadap pembelajaran dengan menerapkan strategi belajar Peta Konsep pada proses pembelajaran. Respon siswa kelas XA dan XB setelah proses pembelajaran disajikan pada Tabel 7 berikut ini.
Tabel 7.Hasil Analisis Respon Siswa

\begin{tabular}{|c|c|c|c|}
\hline No & Uraian & Penilaia & adapat $(96)$ \\
\hline \multirow{8}{*}{ I } & $\begin{array}{l}\text { Bagaimana pendapat Anda terhadap } \\
\text { lkomponen-komponen ini? }\end{array}$ & Menarik & Tidal Menarik \\
\hline & 1. Materilsi pelajaran & 87,72 & 12,28 \\
\hline & 2. Lembar Kegiatan Siswa (LKS) & 96,49 & 3,51 \\
\hline & 3. Buku Siswa & 78,95 & 21,05 \\
\hline & 4. Cara Mengajar Guru & 91,23 & 8,77 \\
\hline & 5. Suasana belajar yang dilatilkan guru & 94,74 & 5,26 \\
\hline & $\begin{array}{l}\text { 6. Tahap - tahapan yang diarahkan guru dahm } \\
\text { proses pembelajaran }\end{array}$ & 89,47 & 10,53 \\
\hline & \begin{tabular}{|l|} 
Persentase Rata-rata \\
\end{tabular} & 89,77 & 10,23 \\
\hline \multirow{6}{*}{ II } & $\begin{array}{l}\text { Apakah Anda merasa baru terhadap } \\
\text { komponen-komponen berilkut? }\end{array}$ & Baru & Tidalk Baru \\
\hline & 1. Lembar Kegiatan Siswa (LKS) & 100 & 0 \\
\hline & 2. Buku Siswa & 78,95 & 21,05 \\
\hline & 3. Suasama belajar yang dilatiklan guru & 94,74 & 5,26 \\
\hline & 4. Cara guru mengajar & 80,70 & 19,30 \\
\hline & Persentase Rata-Rata & 88,60 & 11,40 \\
\hline \multirow{6}{*}{ III } & $\begin{array}{l}\text { Apakah Anda merasa baru terhadap } \\
\text { lkomponen-komponen berilkat? }\end{array}$ & Baru & Tidal: Baru \\
\hline & 1. Menentukan konsep & 100 & 0 \\
\hline & 2. Menentukan sublkonsep & 100 & 0 \\
\hline & $\begin{array}{l}\text { 3. Meletakkan konsep dan sublonsep pada } \\
\text { skema yang tehh disedialsan }\end{array}$ & 100 & 0 \\
\hline & $\begin{array}{l}\text { 4. Melengkapi skema dengan kata penghrubung } \\
\text { sehingga terbennuk peta konsep }\end{array}$ & 100 & 0 \\
\hline & Persentase Rata-Rata & 100 & 0 \\
\hline \multirow{5}{*}{ TV } & \begin{tabular}{|l|} 
Bagaimana pendapat Anda terhadap \\
komponen-komponen ini?
\end{tabular} & Senang & Tidak Senang \\
\hline & 1. Menentukan konsep & 87,72 & 12,28 \\
\hline & 2. Menentukan sublkonsep & 87,72 & 12,28 \\
\hline & $\begin{array}{l}\text { 3. Meletakkan konsep dan sublonsep pada } \\
\text { skema yang telah disediakan }\end{array}$ & 85,96 & 14,04 \\
\hline & $\begin{array}{l}\text { 4. Melenglsapi skema dengan kata penghnbung } \\
\text { sehingga terbennuk peta konsep }\end{array}$ & 85,96 & 14,04 \\
\hline \multirow[t]{2}{*}{ No } & Uraian & \multicolumn{2}{|c|}{ Penilaian/Pendapat (96) } \\
\hline & Persentase Rata-Rata & 86,84 & 13,15 \\
\hline \multirow{6}{*}{$\mathrm{v}$} & $\begin{array}{l}\text { Apakah Anda dapat mengilkuti komponen- } \\
\text { komponen berikut? }\end{array}$ & Mudah & Tidak Mudah \\
\hline & \begin{tabular}{|l|} 
1. Menentukan konsep \\
\end{tabular} & 87,72 & 12,28 \\
\hline & 2. Menentukan sublionsep & 82,46 & 17,54 \\
\hline & $\begin{array}{l}\text { 3. Meletakkan konsep dan sublonsep pada } \\
\text { skema yang tehh disediakan }\end{array}$ & 84,21 & 15,79 \\
\hline & $\begin{array}{l}\text { 4. Melengkapi skema dengan kata penghubung } \\
\text { sehingga terbenrul peta konsep }\end{array}$ & 96,49 & 3,51 \\
\hline & \begin{tabular}{|l|} 
Persentase Rata-Rata \\
\end{tabular} & 87,72 & 12,28 \\
\hline \multirow{2}{*}{ VI } & \multirow{2}{*}{$\begin{array}{l}\text { Apakah Anda berminat untuk mengilkuti } \\
\text { pembelajaran seperti yang telah Anda } \\
\text { lakulkan saat ini pada kegiatan } \\
\text { pembelajaran berikutnya? }\end{array}$} & Berminat & Tidak Berminat \\
\hline & & 82,46 & 17,54 \\
\hline & Persentase rata-rata seluruh aspelk & 89,23 & 10,77 \\
\hline
\end{tabular}

Berdasarkan hasil analisis respon siswa kelas XA dan $\mathrm{XB}$ terhadap pengembangan perangkat pembelajaran (yang meliputi: Buku Ajar Siswa dan Lembar Kegiatan Siswa), diperoleh hasil rata-rata sebanyak $89,23 \%$ siswa merespon menarik dan baru dengan kata lain siswa merespon positif terhadap proses pembelajaran yang telah dilaksanakan (Riduwan, 2010), sedangkan hasil analisis respon siswa terhadap komponen-komponen pembelajaran (yang meliputi: menentukan konsep utama dan konsep yang relevan serta melengkapinya dengan kata penghubung dalam membuat peta konsep), diperoleh hasil bahwa sebanyak $100 \%$ siswa merespon baru dan banyak siswa merasa senang terhadap hal tersebut (siswa merespon positif) dengan kriteria sangat kuat (Riduwan, 2010). 
Hasil analisis ketuntasan dari masing-masing indikator pemahaman konsep dan kemampuan berpikir kritis berdasarkan materi pembelajaran yang telah dikembangkan disajikan pada Tabel 8 dan Tabel 9 berikut ini.

Tabel 8. Hasil Analisis Ketuntasan Indikator Kemampuan Berpikir Kritis

\begin{tabular}{|c|c|c|c|c|c|c|c|c|c|}
\hline \multirow{3}{*}{ No } & \multirow{3}{*}{$\begin{array}{c}\text { Indikator } \\
\text { Pembelajaran }\end{array}$} & \multicolumn{4}{|c|}{$\begin{array}{l}\text { Ketuntasan Indikator } \\
\text { Pembelajaran (\%) }\end{array}$} & \multicolumn{4}{|c|}{ Keterangan } \\
\hline & & \multicolumn{2}{|c|}{$\mathrm{XA}$} & \multicolumn{2}{|c|}{ X B } & \multicolumn{2}{|c|}{$\mathrm{XA}$} & \multicolumn{2}{|c|}{ X B } \\
\hline & & 01 & 02 & 01 & 02 & 01 & 02 & 01 & 02 \\
\hline 1 & Menganalisis & 0 & 75 & 0 & 75,86 & TT & $\mathrm{T}$ & TT & $\mathrm{T}$ \\
\hline 2 & Mendefinisikan Istilah & 0 & 80,36 & 0 & 81,03 & TT & $\mathrm{T}$ & TT & $\mathrm{T}$ \\
\hline 3 & $\begin{array}{l}\text { Memberikan } \\
\text { Penjelasan Sederhana }\end{array}$ & 0 & 75 & 0 & 77,59 & TT & $\mathrm{T}$ & TT & $\mathrm{T}$ \\
\hline 4 & Menarik Kesimpulan & 0 & 76,79 & 0 & 79,31 & TT & $\mathrm{T}$ & TT & $\mathrm{T}$ \\
\hline 5 & $\begin{array}{l}\text { Kemampuan } \\
\text { Memberikan Alasan }\end{array}$ & 0 & 62,50 & 0 & 75,86 & TT & TT & TT & $\mathrm{T}$ \\
\hline & Rerata & 0 & 73,93 & 0 & 77,93 & & & & \\
\hline
\end{tabular}

Tabel 9. Hasil Analisis Ketuntasan Indikator Pemahaman Konsep

\begin{tabular}{|c|c|c|c|c|c|c|c|c|c|}
\hline \multirow{3}{*}{ No } & \multirow{3}{*}{$\begin{array}{l}\text { Indikatoor } \\
\text { Pembelajuran }\end{array}$} & \multicolumn{4}{|c|}{ 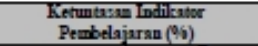 } & \multicolumn{4}{|c|}{ Keteraggan } \\
\hline & & \multicolumn{2}{|c|}{$\mathrm{XA}$} & \multicolumn{2}{|c|}{$\mathrm{XB}$} & \multicolumn{2}{|c|}{$\mathrm{XA}$} & \multicolumn{2}{|c|}{$\mathrm{XB}$} \\
\hline & & 01 & 02 & ol & 02 & 01 & 02 & o1 & 02 \\
\hline 1 & 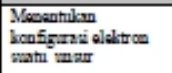 & 32,14 & 87,50 & 31,03 & 84,48 & $\mathrm{TT}$ & T & TT & $\mathrm{T}$ \\
\hline 2 & 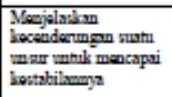 & 12,50 & 85,71 & 13,79 & 75,86 & $\mathrm{TT}$ & T & TT & $\mathrm{T}$ \\
\hline 3 & 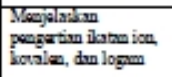 & 11,90 & 82,14 & 11,49 & 77,01 & $\mathrm{TT}$ & T & TT & $\mathrm{T}$ \\
\hline 4 & 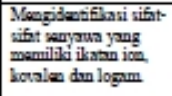 & 11,90 & 78,57 & 11,49 & 75,86 & $\mathrm{TT}$ & $\mathrm{T}$ & TT & $\mathrm{T}$ \\
\hline 5 & 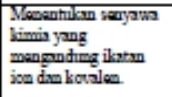 & 10,71 & 78,57 & 10,34 & 79,31 & TT & T & TT & $\mathrm{T}$ \\
\hline 6 & 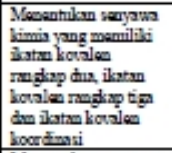 & 6,25 & 75,89 & 6,03 & 76,72 & $\mathrm{TT}$ & T & TT & $\mathrm{T}$ \\
\hline 7 & 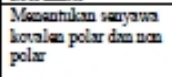 & 8,93 & 78,57 & 8,62 & 75,86 & $\mathrm{TT}$ & T & TT & T \\
\hline 8 & 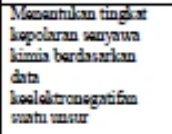 & 7,14 & 76,79 & 6,90 & 77,59 & $\mathrm{TT}$ & T & TT & $\mathrm{T}$ \\
\hline & Rerata & 12,68 & 80,99 & 12,46 & 77,84 & & & & \\
\hline
\end{tabular}

Seluruh butir soal Tes Hasil Belajar pemahaman konsep dan kemampuan berpikir kritis yang dikembangkan dikategorikan ke dalam soal yang sensitif karena memiliki nilai sensitivitas $>0.3$. Sensitivitas butir soal tersebut mengindikasikan adanya efek dari proses kegiatan belajar mengajar yang telah dilakukan. Hasil analisis sensitivitas butir soal pemahaman konsep dan kemampuan berpikir kritis dapat dilihat pada Tabel 10 dan Tabel 11 berikut ini.
Tabel 10. Hasil Analisis Sensitivitas Butir Soal Pemahaman Konsep

\begin{tabular}{|c|c|c|c|c|}
\hline \multirow{2}{*}{ Butir Soal } & \multicolumn{2}{|c|}{ Jumlah Jxwaban Benar } & \multirow{2}{*}{ Sensitivitas } & \multirow{2}{*}{ Karegori } \\
\hline & Prerest & Postest & & \\
\hline 1 & 26 & 57 & 0.54 & Senvitif \\
\hline 2 & 10 & 41 & 0.54 & Senvitif \\
\hline 3 & 15 & 48 & 0.58 & Senvitif \\
\hline 4 & 12 & 44 & 0.56 & Senvitif \\
\hline 5 & 8 & 47 & 0.68 & Senvitif \\
\hline 6 & 16 & 43 & 0.47 & Senvitif \\
\hline 7 & 10 & 46 & 0.63 & Senvitif \\
\hline 8 & 6 & 45 & 0.70 & Senvitif \\
\hline 9 & 6 & 45 & 0.68 & Senuitif \\
\hline 10 & 2 & 41 & 0.68 & Senvitif \\
\hline 11 & 8 & 44 & 0.63 & Senvitif \\
\hline 12 & 2 & 43 & 0.72 & Senvitif \\
\hline 13 & 6 & 42 & 0.63 & Senvitif \\
\hline 14 & 0 & 43 & 0.75 & Senvitif \\
\hline 15 & 6 & 44 & 0.67 & Senvitif \\
\hline 16 & 2 & 42 & 0.70 & Sensitif \\
\hline 17 & 8 & 43 & 0.61 & Senvitif \\
\hline 18 & 2 & 45 & 0.75 & Senvitif \\
\hline 19 & 6 & 45 & 0.68 & Sensitif \\
\hline 20 & 2 & 43 & 0.72 & Senvitif \\
\hline
\end{tabular}

Tabel 11. Hasil Analisis Sensitivitas Butir Soal Kemampuan Berpikir Kritis

\begin{tabular}{|c|c|c|c|c|}
\hline \multirow{2}{*}{ No } & \multicolumn{2}{|c|}{ Jumlah Skor } & \multirow{2}{*}{ Sensitivitas } & \multirow{2}{*}{ Kategori } \\
\cline { 2 - 3 } & Pretest & Postest & & \\
\hline 1 & 0 & 44 & 0.77 & Sensitif \\
\hline 2 & 0 & 42 & 0.74 & Sensitif \\
\hline 3 & 0 & 45 & 0.79 & Sensitif \\
\hline 4 & 0 & 47 & 0.82 & Sensitif \\
\hline 5 & 0 & 41 & 0.72 & Sensitif \\
\hline 6 & 0 & 46 & 0.81 & Sensitif \\
\hline 7 & 0 & 44 & 0.77 & Sensitif \\
\hline 8 & 0 & 45 & 0.79 & Sensitif \\
\hline 9 & 0 & 36 & 0.63 & Sensitif \\
\hline 10 & 0 & 43 & 0.75 & Sensitif \\
\hline
\end{tabular}

Adanya peningkatan pemahaman konsep dan kemampuan berpikir kritis siswa diperoleh dengan menggunakan data pretest dan posttest Tes Hasil Belajar pemahaman konsep dan kemampuan berpikir kritis siswa pada tiap kelas yang diuji dengan menggunakan uji Wilcoxon dengan taraf signifikansi $\alpha$ $=0.05$ (2-tailed). Hasil uji wilcoxon dari data tersebut menunjukkan bahwa nilai sig. $<0.05$, hal tersebut mengindikasikan adanya peningkatan pemahaman konsep dan kemampuan berpikir kritis siswa secara signifikan setelah proses pembelajaran pada setiap kelas.

Tabel 12. Hasil uji Wilcoxon Data Pretest dan Postest Pemahaman Konsep Siswa

\begin{tabular}{|c|c|c|c|c|}
\hline $\begin{array}{c}\text { Data } \\
\text { Pretest-Posttest }\end{array}$ & Mean & $Z$ & $\begin{array}{c}\text { Asymp. Sig. } \\
\text { (2-tailed) }\end{array}$ & Simpulan \\
\hline XA & $\begin{array}{r}0.00 \\
14.50\end{array}$ & $-4.638^{\mathrm{a}}$ & .000 & Ho Ditolak \\
\hline XB & $\begin{array}{r}12.07 \\
15.31\end{array}$ & $-2.702^{\mathrm{a}}$ & .007 & Ho Ditolak \\
\hline
\end{tabular}


Tabel 13. Hasil uji Wilcoxon Data Pretest dan Postest Kemampuan Berpikir Kritis Siswa

\begin{tabular}{|c|c|c|c|c|}
\hline $\begin{array}{c}\text { Data } \\
\text { Pretest-Posttest }\end{array}$ & Mean & $Z$ & $\begin{array}{c}\text { Asymp. Sig. } \\
\text { (2-tailed) }\end{array}$ & Simpulan \\
\hline XA & $\begin{array}{c}0.00 \\
14.50\end{array}$ & $-4.627^{\mathrm{a}}$ & .000 & Ho Ditolak \\
\hline XB & $\begin{array}{c}0.00 \\
15.00\end{array}$ & $-4.712^{\mathrm{a}}$ & .000 & Ho Ditolak \\
\hline
\end{tabular}

\section{PENUTUP}

\section{A. Simpulan}

Berdasarkan hasil analisis, diskusi dan temuan penelitian, maka dapat dibuat kesimpulan bahwa perangkat pembelajaran berbasis strategi belajar Peta Konsep pada pokok bahasan Ikatan Kimia yang dikembangkan telah valid, praktis, dan efektif untuk meningkatkan pemahaman konsep dan kemampuan berpikir kritis siswa

\section{B. Saran}

1. Penerapan rencana pelaksanaan pembelajaran sudah baik namun guru harus lebih bisa mengelola waktu ketika memberikan proses Scaffolding kepada siswa baik pada awal proses pembelajaran maupun ketika siswa membuat peta konsep di dalam LKS agar waktu pembelajaran bisa berjalan lebih efektif dan efisien.

2. Disarankan peneliti-peneliti selanjutnya memberikan gambaran dengan jelas kepada siswa dan guru tentang pembelajaran yang menerapkan strategi belajar Peta Konsep baik dari segi proses pelaksanaan di dalam kelas maupun dalam proses pembuatan perangkat pembelajaran yang berbasis strategi belajar Peta Konsep.

3. LKS dan buku ajar siswa yang digunakan pada saat pembelajaran lebih baik dibagikan kepada siswa sebelum pembelajaran dilaksanakan sehingga siswa lebih mudah dalam memahami LKS tersebut,

4. Peneliti selajutnya untuk penediharapkan dapat melanjutkan penelitian tersebut pada materi Kimia yang lain untuk meningkatkan pemahaman konsep dan kemampuan berpikir kritis siswa.

\section{DAFTAR PUSTAKA}

Arends, R. (2012). Learning To Teach, Ninth Edition. New York: Mc-Graw Hill.

Aziz, Z. dan Jair,N. (2009). Penggunaan Peta Konsep untuk Meningkatkan Pencapaian Mata Pelajaran Sejarah bagi Pelajar Tingkatan Dua. Jurnal Pendidikan Malaysia. Vol 34 No. 1 pp. $3-15$.

Chiou,C.C. (2008). The Effect of Concept Mapping on Students' Learning Achievements and Interests. Innovations in Education and
Teaching International. Vol 45 No. 4 pp. 375 $-387$.

Dahar, R.W. (1988). Teori-Teori Belajar. Jakarta: Departemen Pendidikan dan Kebudayaan Dirjen Dikti.

Dahar, R.W. (2011). Teori-Teori Belajar. Cetakan ke14. Jakarta: Penerbit Erlangga.

Elvinawati. (2011). Optimalisasi Pembelajaran Kimia Pemisahan Melalui Penerapan Pendekatan Konstruktivisme dan Model Peta Konsep. Jurnal Exacta. Vol 9 No. 1 Juni 2011. halaman. $23-28$.

Ibrahim, M. (2012). Konsep, miskonsepsi dan Cara Pembelajarannya. Surabaya: Unesa University Press

Juliarti, Rambe, A., Sutanti, S.,\& Estellita, D.D. (2012). Penerapan Metode Pembelajaran Peta Konsep untuk Meningkatkan Motivasi dan Hasil Belajar Pada Mata Kuliah Statistik . Vol 28 No. 8 2012. pp. 228 - 241.

Kementerian Pendidikan dan Kebudayaan.(2013). Modul Pelatihan Implementasi Kurikulum 2013. Jakarta: Badan Pengembangan Sumber Daya Manusia Pendidikan dan Kebudayaan dan Penjaminan Mutu Pendidikan.

Kilic and Cakmak, (2013). Concept Map as Tool Form Meaningful Learning and teaching in Chemistry Education. International Journal on New Trends in Education and Their Implications. Vol 4 No. 3 October 2013. pp. $152-164$.

Markow,P.G. and Lonning,R.A. (1998). Usefulness of Concepts Map in College Chemistry Laboratories: Students' Perceptions and Effects on Achievement. Journal of Research in Science Teaching. Vol 35 No. 9 Februari 1998. pp. 1015 - 1029.

Middlecamp, C. \& Kean, E. (1985). Panduan belajar kimia dasar. Jakarta: Gramedia.

Nieveen, N. (1999). Prototyping to Reach Product Quality. In J. v. Akker, R. Branch, K. Gustafson, N. Nieveen, \& T. Plomp, Design Approaches and Tools in Education and Training (pp. 125-135). Dordrecht, Netherland: Kluwer Academic Publishers.

Nur, M. (2011). Keterampilan-Keterampilan Proses Sains. Surabaya: Unesa University Press.

Novak, D.J., \& Gowin, D.B. (1984). Learning How to Learn. New York: Cambridge University Press.

Otor and Emanuel, E. (2013). Effect of Concept Mapping Strategy on Students' Achievement in Difficult Chemistry Concepts in Rural and Urban In Benue State. Case Studies Journal. Vol 4 No. 3 October 2013. pp. 16 - 20. 
Ratumanan, G.T., dan T, Laurens. (2006). Evaluasi Hasil yang Relevan dengan Memecahkan Problematika Belajar dan Mengajar. Bandung:CV Alfabeta.

Riduwan. (2010). Skala Pengukuran Variabel Variabel Penelitian. Bandung: Alfabeta.
Slavin, R.E. (2006). Educational Psychology. Theory and Practice. $8^{\text {th }}$ Edition. Boston: Pearson Education, Inc.

Vanides, Yin, Y., Tomita, M.,\& Ruiz Primo, M.A. (2005). Using Concept Maps in the Science Classroom. Journal of Science Scope. Vol 28 No. 8 Summer 2005. pp. $27-31$. 